\title{
THE ASSOCIATION OF RECURRENT ABDOMINAL PAIN AND HELICOBACTER PYLORI INFECTION IN CORRELATION WITH ESOPHAGOGASTRODUODENOSCOPY FINDINGS
}

\author{
Osmancevic Lejla, ${ }^{1}$ Osmancevic Emir ${ }^{2}$ \\ ${ }^{1}$ Pediatric Clinic, University Clinical Center Tuzla, Tuzla, Bosnia and Herzegovina \\ ${ }^{2}$ Faculty of Medicine, University of Tuzla, Tuzla, Bosnia and Herzegovina
}

Primljen/Received 08. 06. 2020. god.

Prihvaćen/Accepted 30. 07. 2020. god.

Abstract: Aim: The aim of this research was to determine the association of recurrent abdominal pain and Helicobacter pylori (H. pylori) infection in childhood, in correlation with the finding of an upper endoscopy.

Introduction: Recurrent abdominal pain (RAP) was defined according to Apley and Naish's criteria from the year 1959 as at least three or more episodes of abdominal pain lasting longer than three months in children older than 3 years, and severe enough to prevent normal activities in child. The association of RAP and $\mathrm{H}$. pylori has been analyzed in several different researches, and there are conflicting results about their interconnection.

However, the ethiological association of the presence of H. pylori with the onset and development of acute and chronic active gastritis and duodenal ulcer is known.

Matrherial and method: The research protocol included a total of $77 / 183(42.07 \%)$ children divided by age into three subgroups: preschool age ( 3 to 6.9 years), school age (7 to 10.9 years) and adolescent age (11 to 15 years) in whom the diagnosis of RAB was determined by meeting the criteria according to Apley and Naish (1959), and the American Academy of Pediatrics (2005). H. pylori infection was confirmed by enzyme- linked immunosorbent assay (ELISA), while esophagogastroduodenoscopy was performed by the device for upper endoscopy type Olimpus GIF Type Q156, in the endoscopic cabinet of the Clinic for Internal Medicine, University Clinical Center Tuzla.

Results: Of the total number of examined children (77), the analyse of Helicobacter pylori infection presence showed the biggest number of positive findings in school age $91.3 \%$, in adolescent age $78.0 \%$, while the smallest number was in preschool age $(25.0 \%)$. The most common findings of upper endoscopy and microscopic findings were described as: antritis acuta in $16 \%$, gastritis chronica activa et erosiva in $32 \%$, and duodenitis acuta $(12 \%)$.

Conclusion: A significant association of H. pylori infection and RAP are confirmed by positive finding of esophagogastroduodenoscopy, leading to conclusion that immunological testing for the presence of this bacteria is justified. After obtaining a positive finding with confirmed infecion, it is necessary to start with the treatment.

Key words: recurrent abdominal pain, Helicobacter pylori, esophagogastroduodenoscopy.

\section{INTRODUCTION}

For many years recurrent abdominal pain (RAP) has been defined in the world literature according to generally accepted criteria proposed by Apley and Naish in the year 1959 as follows: at least three or more episodes of abdominal pain lasting longer than three months in children older than 3 years, and severe enough to prevent normal activities in child (1).

Abdominal pain is one of the most common childhood symptom occuring in $9 \%$ to $16 \%$ of children, and accounts for $35 \%$ to $45 \%$ of all examinations in specialists gastroenterology ambulants $(2,3)$. Although the exact RAP prevalence cannot be determined, this diagnosis is considered to be responsible for $2 \%$ to $4 \%$ of all visits to a specialist pediatrician in America, while $13 \%$ to $19 \%$ of all school children experience this painful episode at least once a week. As Andrews et al. point out, RAP combined with other symptoms greatly disturbs not only school activities and psychosocial 
function, but also disturbs the overall quality of life of the child and his family (4).

Most basic printbooks cite the entire array of possible causes of abdominal pain on the basis of which the division of RAP into organic, functional (nonspecific) and psychogenic is made $(5,6,7)$. Organic causes of pain have their ethiology intraabdominally, and they are the result of the presence of abnormal anatomical, structural or disordered physiological processes such as inflammatory, metabolic, infectious and neoplastic changes $(7,8)$.

Seng Hock Quak (8) and Bufler at al. (9) defined the most common organic causes of recurrent abdominal pain:

- food intolerance (primary or secundary lactose intolerance, fructose malabsortion)

- gastroesophageal reflux and sophagitis (oesinophilic esophagitis),

- peptic ulcer with or wihout Helicobacter Pylory infection,

- chronic inflammatory bowel disease (Chron's disease, ulcerative colitis),

- gluten enteropathy,

- diseases of the hepatobiliary tract,

- pancreatitis,

- anatomical malformations (Mekel's diverticulum, intenstinal malrotations and duplications, annular pancreas),

- infectious intenstinal diseases (Yersinia enetrocolica, Yersinia pseudotuberculosis, Entameba hystolitica, parasitosis)

- neoplasms,

- dysmenorrhea,

- urinary tract infection $(8,9)$.

The association of RAP and H. pylori infection has been analyzed in several different studies, and there are conflicting results about their interconnection $(10,11,12)$.

The ethiological association of the presence of $\mathrm{H}$. pylori with the onset and development of acute and chronic active gastritis, duodenal ulcer and malignant diseases such as gastric lymphomas and adenocarcinomas is known $(13,14)$. Although opinions on the presence of H. pylori in children with RAP are divided (15, $16)$, recent studies that have been made worldwide suggest their significant association $(2,11,12,17)$.

Helicobacter pylori is a gram- negative, microaerophilic, spiral-shaped bacteria of high motility from spirillacea family, and it has 4-6 unipolar flagella. This bacteria lives within the gastric mucus layer overlying the gastric epithelial cells. To survive in the hostile acid environment of the stomach, H. pylori produces the enzyme urease which converts urea from gastric acid into ammonia and carbon dioxide, whereby reduces acidity and creates favorable conditions for life of this bacteria. This feature of H. pylori forms the basis for some diagnostic tests such as rapid ureasa test and urea breath test.

Many recent studies have confirmed that the only known source of $\mathrm{H}$. pylori infection are humans. The route of transmission of the infection is mainly by oro-oral, faeco-oral and gastric-oral route. H. pylori is mainly transmitted within families, from parents to children, respectively from the elderly of the third generation to their children, as well as between siblings. Researches data confirm that transmission from children to children is most common in overcrowded schools, also in insitutions for care of children with disabilities. Immigrants who arrived from underdeveloped countries, American- born children whose parents are immigrants, and even children who are adopted from developing countries form a group of a high risk individuals carrying the bacteria $H$. pylori $(17,18)$.

The role of $\mathrm{H}$. pylori infection in the onset of RAP is not significant because it is considered that this bacteria does not cause stomach pain $(13,14)$, while research from from the year 2012 suggests that there is no direct connection of RAP with $\mathrm{H}$. pylori infection. There was no statistically significant difference between the group of $\mathrm{H}$. pylori positive and negative children in the symptoms of RAP, as well as the symptoms of vomiting and sideropenic anemia (18). According to Nasphgan's recommendation, the aim of diagnostic procedures in the onset of RAP in children is to determine the cause of present symptoms before determining the presence of $\mathrm{H}$. pylori infection $(7,19)$.

\section{Significance \\ of esophagogastroduodenoscopy in the differential diagnosis of recurrent abdominal pain}

Esophagogastroduodenoscopy (EGD) has become a common procedure in the evaluation of RAP in children. According to the research results by the Pediatric Endoscopy Databases System-Clinical Outcomes Research Initiative (PED-CORI), endoscopy finding was positive in $38 \%$ of children with a positive anamnesis of recurrent abdominal pain, whereby this endoscopic procedure was justified (20). Most authors state that EGD is not recommended in the evaluation of RAP without clearly defined symptoms of the disease $(21,22,23)$.

The definition of functional gastrointenstinal pain in children based on the Rome II criteria fully meets the RAP criteria set by the North American Society for Pediatric Gastroenterology, Hepatology and Nutrition (NASPGHAN) (5). They state that negative EGD does not confirm the functional etiology of RAP, respecti- 
vely it does not exclude the possibility of organic basis for disease of the gastrointenstinal tract (21).

According to NASPGHAN there is no significant justification for EGD in children with RAP who do not show warning symptoms such as: involuntary weight loss ( $>10 \%$ of body weight), delayed linear growth, gastrointenstinal bleeding, significant vomiting, chronic diarrhea, nocturnal pain that disrupts child's sleep, positive familiy history on inflammatory bowel disease, unexplained fever, delayed puberty, reproductive system disturbances, dysuria, arthritis $(7,9,24)$, or warning signs such as: enlargement of the abdomen, presence of pathological peristalsis, any abnormal palpation finding of the abdomen and typical localization of pain in the right upper and the lower quadrant of the abdomen (9).

The importance of EGD is not only based on adequate diagnosis, but also on the need to eliminate the symptoms and signs of RAP, respectively in the application of therapeutic treatment that will enable recovery from the underlaying pathogen and allow the child and his family to return to everyday activities (2). Frank at al. in their study highlight the importance of eradicating $\mathrm{H}$. pylori infection for the prevention of gastric and duodenal ulcers in childhood and the possibility of gastric cancer in adulhood (25). The aim of this research was to determine the association of recurrent abdominal pain and Helicobacter pylori infection in childhood, in correlation with the finding of an upper endoscopy.

\section{PATIENTS AND METHODS}

The prospective research in the examined period from 1st December 2011. to 1st December 2012., conducted in an Outpatient clinic for gastroenterology and the Department for gastroenterology, Clinic for children's diseases, University Clinical Center Tuzla (UCC) included 1013 children aged 3-15 years old, of whom RAP had 183/1013 (18.6\%) children. From total number of respondents, 106 children did not meet the research criteria. All data of our patients were acquired based on available medical documentation (illness history and medical charts), questionnaire, physical examination and laboratory findings. Data for questionnaires was gathered from parents of patients, with their consent in accordance with procedure in UCC Tuzla.

Inclusion criteria for the research were:

- The diagnosis of RAP was established by meeting Apley and Naish (1) and the American Academy for Pediatrics (24) criteria, which included more than three episodes of abdominal pain that occur over at least three months in children older than 3 years, severe enough to affect the child's ability to perform normal activities, and require intervention by the doctor $(1,24)$.
- that the patients are up to 15 years of age on the day of examination.

The study included 183 children of whom two groups were formed; examined group $\mathrm{N}=70$ with a positive finding of esophagogastroduodenoscopy and control group $\mathrm{N}=7$ children with a negative finding of esophagogastroduodenoscopy. Respondents of both groups were also divided according to age into three subgroups:

- preschool age (from 3 to 6.9 years)

- school age (from 7 to 10.9 years) and

- adolescence (from 11 to 15 years)

Criteria for excluding respondents from the study were: failure to meet the criteria for the diagnosis of $\mathrm{RAB}$ according to the stated criteria, that the ages are under 3 years and over 15 years on the day of the examination, children with cystic fibrosis, children with organ transplants, Down syndrome, cerebral palsy, microcephaly and neurodegenerative diseases because in these children the etiology of pain differs significantly from the general population, have used proton pump inhibitor therapy, metronidazole or clarithromycin for at least two weeks before the test, children after thoracic and abdominal surgery, respondents for whom we did not obtain written consent for inclusion in the survey.

Indications for esophagogastroduodenoscopy in children with RAP were based on the following criteria: anamnestic data on the presence of at least two warning signs and/or one warning sign, one or more positive immunological finding.

Specific serological tests were determined by common methods at the Polyclinic for laboratory diagnostics- Department for microbiology- Department for immunology, University Clinical Center Tuzla. Confirmation of $\mathrm{H}$. pylori infection was doneby enzymelinked immunosorbent assay (ELISA) (Enzyme IgA, IgM, IgG, SIMENS, Marburg, Germany).

Esophagogastroduodenoscopies were performed in the endoscopic cabinet, Clinic for Internal Medicine, University Clinical Center Tuzla by the device for upper endoscopy type Olimpus GIF Type Q156. Diagnostically significant endoscopic and pathohistological finding of biopsy were those that potentially have diaganostic and therapeutic value. In cases when the upper endoscopy finding was pathologically altered (esophagus, ventricle or duodenum) at least one biopsy sample was taken from the altered area. The justification of this methodological approach to children with RAP is also confirmed by the results of researh in which no statistical significance of biopsy in the case of normal endoscopy finding was recorded $(11,26,27,28)$.

The descriptions of endoscopic findings such as: mucosal erythema, reduced or absent vascular pattern of mucosa or redness, as well as the descriptions of pat- 
hological findings defined as reactive changes, mucosal edema or moderate inflammatory changes were not included in this research (11).

A biopsy finding of the endoscopically altered mucosa of the esophagus, ventricle (antrum, and fundus) or duodenum was classified as negative, suspected, and positive. Interpretation of the histological finding was performed blindly by a pathologist who was unfamiliar with the history of the disease, the endoscopic finding, and the immunological values of the antibody.

1. Negative score was defined as a pathohistological change based on the following characteristics, for esophagus: normal type of mucosa without the presence of basal hypereplasia and absent intraepithelial eosinophils; for antrum and ventricular funuds: normal type of mucosa; for duodenum: normal villous.

2. Ambiguous or suspicious score referred to moderate pathohistological changes, for esophagus: minimal or moderate basal hypereplasia, vascular ectasia and rare intraepithelial lymphocytes or eosinophils; for antrum and ventricular fundus: rare occurrence of lymphoids in groups; for duodenum: villi fragmented distributed with sparse inflammatory cells.

3. Positive score was defined as significant pathohistological changes, for esophagus: basal hyperplasia, vascular ectasia and numerous intraepithelial eosinophils and lymphocytes; for antrum and ventricular fundus: lymphocyte aggregation; for duodenum: crypto hyperplasia, villous atrophyte and increased number of intraepithelial lymphocytes.

Statistical analysis was performed with biomedical application software called "MedCalc for Windows, version 114.4". For statistical significance of value " $p$ " the usual level of significance, $p<0.05$, was chosen (29).

\section{RESULTS}

A positive finding of esophagogastroduodenoscopy on the whole sample had 70 (91\%) children, while $7(9 \%)$ had a negative finding. The ratio of a pos-

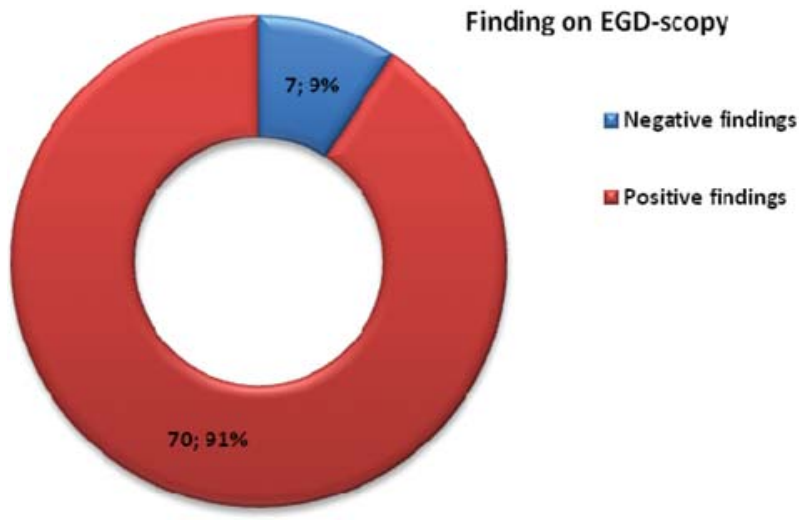

Figure 1. EGD finding in patients with RAP symptoms

itive and negative findings was 9: 1 . The results of this part of research are shown in Figure 1.

Of the 77 children who entered the study protocol, $47(61 \%)$ were female and $30(39 \%)$ were male. Female subjects were more represented, with a statistically significant difference (61 vs 39; $\mathrm{p}=0.009$ ). The most common causes of RAP in children recorded in our research were EGD pathological findings, of which the most common were gastropathies (erythematosus and/or erosive)in total of $24 / 30$ or $80 \%$ boys and $35 / 47$ or $74.5 \%$ girls.

Endoscopic findings of duodenogastric reflux were present in $11 / 30$ or $36.6 \%$ of boys and $17 / 47$ or $36.2 \%$ of girls, while hiatal hernia was found much rare and was recorded in $8 / 30$ or $26.6 \%$ of male and $8 / 47$ $(17.2 \%)$ female subjects.

By analyzing the presence of $\mathrm{H}$. pylori infection in children with symptoms of RAP by age groups, we found the biggest number of positive findings in school age in $21 / 23(91,3 \%)$ children aged from 7 to 11,9 years, some less in adolescent group in 39/50 (78,0\%) children aged from 12 to 15 years, while in the preschool group we found the smallest number $1 / 4$ (25\%) child. The results are shown in Table1.

Table 2 shows the pathological values of serologic tests associated with a positive EGD finding in patients with RAP.

Table1. Positivity of $H$. pylori infection findings according to the examined age groups of children with RAP

\begin{tabular}{|c|c|c|c|c|c|c|}
\hline & & & \multicolumn{3}{|c|}{ Group by age } & \multirow{2}{*}{ Total } \\
\hline & & & Preschool age & School age & Adolescent age & \\
\hline \multirow{4}{*}{ H. pylori } & \multirow{2}{*}{$\mathrm{Neg}$} & $\mathrm{N}$ & 3 & 2 & 11 & 16 \\
\hline & & $\%$ & $75.0 \%$ & $8.7 \%$ & $22.0 \%$ & $20.8 \%$ \\
\hline & \multirow{2}{*}{ Pos } & $\mathrm{N}$ & 1 & 21 & 39 & 61 \\
\hline & & $\%$ & $25.0 \%$ & $91.3 \%$ & $78.0 \%$ & $79.2 \%$ \\
\hline \multirow{2}{*}{ Total } & & $\mathrm{N}$ & 4 & 23 & 50 & 77 \\
\hline & & $\%$ & $100.0 \%$ & $100.0 \%$ & $100.0 \%$ & $100.0 \%$ \\
\hline
\end{tabular}


Table 2. The pathological values of serologic tests associated with a positive EGD finding in children with RAP symptoms

\begin{tabular}{|c|c|c|c|c|}
\hline \multicolumn{2}{|c|}{ Parameter } & Frequency & $\mathbf{\%}$ & p-value \\
\hline \multirow{3}{*}{ H. pylori } & Positive & 61 & 79.2 & \multirow{2}{*}{0,053} \\
\cline { 2 - 4 } & Negative & 16 & 20.8 & \\
\cline { 2 - 4 } & Not done & 0 & 0 & \\
\hline
\end{tabular}

*H. pylori (Helicobacter pylori)

Table 3. Relationship of positive histological and EGD findings in subjects with RAB symptoms

\begin{tabular}{|c|c|c|c|c|c|c|c|}
\hline & \multicolumn{4}{|c|}{ Positive histological findings } & \multirow{3}{*}{$\begin{array}{c}\text { Total } \\
7\end{array}$} \\
\hline & & & Pos & Neg & Susp & Wasn't done & \\
\hline \multirow{4}{*}{ Positive EGD } & \multirow{2}{*}{ Neg } & $\mathrm{N}$ & 0 & 0 & 0 & 7 & \\
\hline & & $\%$ & $0.0 \%$ & $0.0 \%$ & $0.0 \%$ & $100.0 \%$ & $100.0 \%$ \\
\hline & \multirow{2}{*}{ Pos } & $\mathrm{N}$ & 25 & 2 & 1 & 42 & 70 \\
\hline & & $\%$ & $35.7 \%$ & $2.9 \%$ & $1.4 \%$ & $60.0 \%$ & $100.0 \%$ \\
\hline \multirow{2}{*}{ Total } & & $\mathrm{N}$ & 25 & 2 & 1 & 49 & 77 \\
\hline & & $\%$ & $32.5 \%$ & $2.6 \%$ & $1.3 \%$ & $63.6 \%$ & $100.0 \%$ \\
\hline
\end{tabular}

Endoscopically confirmed antral and prepyloric gastritis in our research was recorded in $22 \mathrm{H}$. pylori positive children and $10 \mathrm{H}$. pylori negative children, while infection and alteration of the corporal and antral mucosa with prepyloric area was recorded in $7 \mathrm{H}$. pylori positive children, and $6 \mathrm{H}$. pylori negative children.

The descriptions of endoscopic findings such as: mucosal erythema, reduced or absent vascular pattern of mucosa or redness, as well as the descriptions of pathological findings defined as reactive changes, mucosal edema or moderate inflammatory changes were not included in this research. In our endoscopic findings of a large number of patients, gastropathy of antral and prepyloric area was described as alteredhyperemic, edematous or stripped mucosa with single or molten erosive and hemorrhagic fields.

Gastric mucosal biopsy is not always indicated in EDG and it was done in 28 (36.4\%) children, of whom $25(89.3 \%)$ had a positive pathohystological (PHD) finding. The most common microscopic findings were described as antritis acuta in $4(16 \%)$ children, gastritis chronica non atrophica et non erosiva in $2(8 \%)$ children, gastric chronica activa et erosiva in $8(32 \%)$ children, duodenitis acuta in $3(12 \%)$ children, and duodentits chronica ulcerosa in $5(20 \%)$ children, while other children with a positive mucosal biopsy findings had a combination of active chronic gastritis with or without ulcerations and erosions. Of the total number of positive EGD findings (70), a small number of biopsies were recorded, a total of 28 , of which six were biopsy of the small intestinal mucosa and confirmed gluten enteropathy.

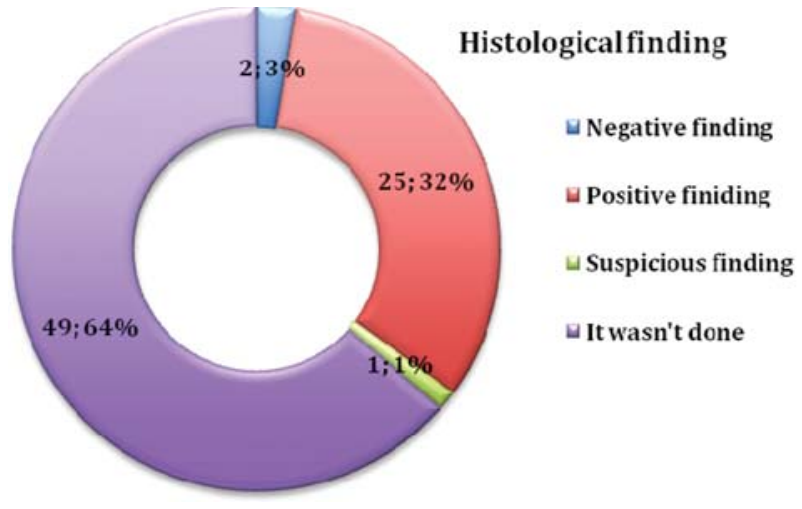

Figure 2. Histological finding of duodenal biopsy in children with RAP symptoms who underwent EGD

A biopsy finding of the endoscopically altered mucosa of the esophagus, ventricle (antrum, and fundus), or duodenum was classified as negative, suspected, and positive. Figure 2 and Table 3 provide a comparative presentation of the histological findings and the findings on EGD-scopy.

\section{DISCUSSION}

In this research we have examined and/or hospitalized 1013 children in an Outpatient clinic for gastroenterology and/or the Department for gastroenterology, Clinic for children's diseases, University Clinical Center Tuzla. Out of this number, 183 (18.06\%) children had RAP. Dhroove at al. (28) recorded that out of 14,836 examined children in Germany, $20 \%$ of them had a RAP prevalence, which partially agrees with the results of our research (28). The best comparison of our 
results and the results of other researches is related to the work of Apley and Naish (1), where in a group of 100 examined children, the incidence of RAP was $10.8 \%$ (9.9\% boys and $12.3 \%$ girls), with the highest incidence at the age of 5 years, and between the age of 8 and 10 years (30).

By analyzing the presence of $\mathrm{H}$. pylori infection according to age groups, we have found the biggest number of a positive findings in the school age group from 7 to 11.9 years $(91.3 \%)$, slightly smaller number in the adolescent age group from 12 to 15 years $(78.0 \%)$, while in the preschool age from 3 to 6.9 years was the smallest number $(25.0 \%)$. Stordal at al. (30) conducted a research in which out of 44 patients the RAP organic etiology was confirmed in $45 \%$ of children, while only one child was positive for H. pylori, which partially agrees with the results of our research (30).

The reserch results from Kumar et al. (26) completely agree with our results, especially when compared with the adolescent age group. They show that out of 55 patients with RAP, $42(75.36 \%)$ of them was positive for $\mathrm{H}$. pylori. The prevalence of $\mathrm{H}$. pylori infection was statistically significantly higher in children with gastritis and duodenal ulcer, while in patients with normal EGD findings H. pylori bacteria was positive in only $25 \%$ of the examined children (26).

In a research Mansoura at al. (27) there was no statistically significant association of $\mathrm{H}$. pylori infection with RAP symptoms. In both examined groups (group I consisted of children with RAP, and group II as a control group consisted of healthy children) the number of H. pylori positive children was $42 \%$ and $45 \%$. The only statistically sigificant difference between these two examined groups was the number of patients with symptoms of vomitig, typical localization of pain and hypochromic anemia. The results obtained by this research agree with the results from our research when it comes to the statistical significance of the association of $\mathrm{H}$. pylori infection and warning symptoms and signs (vomiting, typical localization of pain) (27).

In our research the most common causes of RAP in children described in EGD findings were gastropathies (erythematosus and/or erosive) in $24(83.3 \%)$ boys and 35 (74.4\%) girls. Endoscopic finding of duodenogastric reflux was found in $11(36.6 \%)$ boys and 17 (36.1\%) girls, while hiatal hernia was much rarer condition and it was found in $22 \mathrm{H}$. pylori positive children and $10 \mathrm{H}$. pylori negative children, while infection of the corpora mucosa with alteration of the antral and prepyloric area was found in $7 \mathrm{H}$. pylori positive children and $6 \mathrm{H}$. pylori negative children.

Frank at al. (25) in their research of patients aged 3 to 15 years old with RAP recorded the following results: mean age was 9,2 years, ratio between girls and boys was the same, epigastric pain had $48 \%$ of children infected with H. pylori, diffuse abdominal pain had $52 \%$, and vomiting as a symptom was present in $14 \%$ of children. Among patients with RAP symptoms who were $H$. pylori negative, epigastric pain had $43 \%$, diffuse abdominal pain had $57 \%$, while vomiting was present in $13 \%$ patients proving that there was no statistically significant difference in symptoms and signs in these two groups of examined children. It is noteworthy that there was a statistically significant difference in the upper endoscopy finding in children with positive and negative H. pylori findings. Nodular antral gastropathy was recorded in $69 \%$ of $\mathrm{H}$. pylori positive and only in $2 \% \mathrm{H}$. pylori negative patients, a duodenal ulcer in four or $14 \% \mathrm{H}$. pylori positive patients. The pathohistological finding was not normal in any of patients who were positive to $\mathrm{H}$. pylori, while in $\mathrm{H}$. pylori negative patients there was $66 \%$ with normal pathohistological finding (25).

Baysoy at al. (31) in their researh recorded that positive H. pylori finding had 28 patients out of a total of 52 children, and they underwent EGD. Different degrees of mucosal damage, classsified according to the Sydney score for gastritis from mild to severe degree, were recorded in 26 patients. Antral gastritis had 15 $(53,6 \%)$, corpus gastritis $3 \%$, while pancarditis was recorded in 8 or $28.6 \%$ children (31).

The research of Akbulut et al. (32) also corresponds to results from our research. The importance of upper endoscopy as "the gold standard" remains an irreplaceable method for assessing the association of RAP and H. pylori infection in children, for it allows for a very clear and accurate diagnosis of the disease. Therefore, it is very important to advocate the development of this invasive procedure, especially in uderdeveloped and developing countries $(32,33)$.

\section{CONCLUSION}

It is quite difficult to make the distinction between the organic cause of abdominal pain and the functional etiology of this disease in children. The organic cause of abdominal pain must be precisely defined by using necessary and different diagnostic procedures, just as in the case of functional etiology of the disease, unnecessary and sometimes very painful diagnostic test should be avoided.

In our research the significant association between H. pylori infection and RAP was recorded and confirmed by a positive esophagogastroduodenoscopyfinding, suggesting that immunological processing for the presence of this bacterium is justified. It is necessary to start treatment and $\mathrm{H}$. pylori eradication therapy right away after obtaining a positive finding of infection. 
The importance of serological tests and EGD is not only based on adequate diagnosis, but also on the need to eliminate the symptoms and signs of RAP, respectively the application of therapeutic treatment that will cure the underlying pathogen and allow the child and his family to return to normal, everyday activities.

\author{
Abbreviations \\ RAP - Recurrent abdominal pain \\ ELISA - Enzyme-Linked Immunosorbent Assay \\ EGD - Esophagogastroduodenoscopy
}

NASPGHAN - North American Society for Pediatric Gastroenterology, Hepatology and Nutrition

UCC - University Clinical Center Tuzla

Conflict of Interests: The authors declare that there are no conflicts of interest related to this article.

Funding: None

\section{Licensing}

This work is licensed under a Creative Commons Attribution 4.0 International (CC BY 4.0) License.

\title{
Sažetak
}

\section{POVEZANOST REKURENTNOG ABDOMINALNOG BOLA I INFEKCIJE SA HELICOBACTER PYLORI U KORELACIJI SA NALAZOM EZOFAGOGASTRODUODENOSKOPIJE}

\author{
Osmancevic Lejla, ${ }^{1}$ Osmancevic Emir ${ }^{2}$ \\ ${ }^{1}$ Pediatric Clinic, University Clinical Center Tuzla, Tuzla, Bosnia and Herzegovina \\ ${ }^{2}$ Faculty of Medicine, University of Tuzla, Tuzla, Bosnia and Herzegovina
}

Cilj: Cilj ovog istraživanja je da ispita vezu između rekurentnog abdominalnog bola i infekcije sa Helicobacter pylori (H. pylori) kod dece, u korelaciji sa nalazom ezofagogastroduodenoskopije.

Uvod: Rekurentni abdominalni bol (RAB) je definisan prema kriterijumu iz 1959. godine, koji su dali Apley i Naish, kao najmanje tri ili više epizoda abdominalnog bola koje traju duže od tri meseca, kod dece starije od 3 godine i koje su toliko jake da sprečavaju uobičajene aktivnosti kod deteta. Veza između RAB i H. pylori je već analizirana u nekoliko različitih istraživanja i postoje konfliktni rezultati o njihovoj međusobnoj vezi. Ipak, veza između H. pylori i pojave i razvoja akutnog i hroničnog gastritisa, i ulkusa duodenuma je poznata.

Materijal i metode: Istraživanjem je obuhvaćeno ukupno 77/183 dece koja su podeljena u tri grupe: predškolski uzrast (3-6 godina), školski uzrast (7-10,9 godina) i adolescenti (11-1,5 godina), kod kojih je dijagnoza RAP-a postavljena pomoću kriterijuma Apley-a i Naish-a (1959) i Američke Akademije Pedijatara (2005). Infekcija sa H. pylori je potvrđena ELI-

\section{REFERENCES}

1. Apley J, Naish N. Recurrent abdominal pains: A field survey of 1000 school children. Arch Dis Child.1958; 33(168): 165-70.

2. Kalach N, Bontems P, Raymond J. Helicobacter pylori infection in children. Helicobacter. 2017;22 (Suppl 1). doi: 10.1111/hel.12414
SA testom, dok je ezofagogastroduodenoskopija izvedena uz pomoć aparata za gornju endoskopiju Olimpus GIF Type Q156, u endoskopskom kabinetu Klinike za internu medicinu, Univerzitetskog Kliničkog Centra Tuzla.

Rezultati: Od ukupnog broja pregledane dece (77), Helicobacter pylori pozitivnih je najviše bilo među decom školskog uzrasta 91,3\%, kod adolescenata je bilo njih 78,0\%, dok je najmanje pozitivnih na $\mathrm{H}$. pylori bilo među decom predškolskog uzrasta $(25,0 \%)$. Najčešći nalaz dobijen gornjom endoskopijom i mikroskopskom analizom bio je akutni antritis kod 16\% slučajeva, hronični gastritis, aktivni i erozivni kod $32 \%$, i akutni duodenitis (12\%).

Zaključak: Značajna veza infekcije sa $\mathrm{H}$. pylori i RAP-a potvrđena pozitivnim nalazom ezofagogastroduodenoskopije vodi ka zaključku da je imunološko testiranje na prisustvo ove bakterije opravdano. Nakon dobijanja pozitivnog nalaza sa potvrđenom infekcijom neophodno je započeti lečenje.

Ključne reči: rekurentni abdominalni bol, Helicobacter pylori, ezofagogastroduodenoskopija.

3. Kaji E, Yoden A, Otani M, Okuhira T, Aomatsu T, Tamai $\mathrm{H}$ et al.Helicobacter pylori test-and-treat strategy for second-year junior high school students aimed at the prevention of gastric cancer in Takatsuki City. Helicobacter. 2020; 25: e12696.

4. Andrews ET, Beattie RM, Tighe MP. Functional abdominal pain: what clinicians need to know. Arch Dis Child. Published Online First: 09 March 2020. doi: 10.1136/archdischild2020-318825. 
5. Domsa AT, Lupusoru R, Gheban D, Serban R, Borzan CM. Helicobacter pylori Gastritis in Children-The Link between Endoscopy and Histology. J Clin Med. 2020; 9(3): 784.

6. Apley J. "Little bellichres": Prognostic imlication. Pediatria IV, Gastroenterology. 1974; 7: 220-4.

7. Crandall WV, Barnard JA, Cohen MB, Colletti RB, Ferry GD, Harnsberger JK, et al. Pediatric Gastroenterology Work force Survey 2003-04. J Pediatr Gastroenterol Nutr. 2005; 40(4): 397-405.

8. Quek SH. Recurrent abdominal pain in children: a clinical approach. Singapore Med J.2015; 56(3): 125-8.

9. Bufler P, Gross M, Urlig H. Recurrent abdominal pain in childhood. Dtsch Artztebl Int. 2011; 108(17): 295-304.

10. Yang HR. Updates on the diagnosis of Helicobacter pylori infection in children: What are the differences between adults and children? Pediatr Gastroenterol Hepatol Nutr. 2016; 19(2): 96-103.

11. Berger TD, Soffer S, Vuzel-Harel T, Silbermintz A, Fleishaker H, Shamir R, et al. The yield of upper gastrointestinal endoscopy at a Pediatric Tertiary Care Center. Isr Med Assoc J. 2020; 22(3): 164-8.

12. Nakayama Y, Horiuchi A, Kumagai T, S Kubota, Y Taki, S Oishi, et al. Psihiatric, Somatic and gastrointestinal disorder Helicobacter pylori infection in children with recurrent abdominal pain. Arch Dis Child. 2006; 91(8): 671-4.

13. Sherman PM. Appropriate strategies for testing and treating Helicobacter pylori in children: When and How. Am J Med. 2004; 117(Suppl 5A): 30-5.

14. De Giacomo C, Valdambrini V, Lizzoli F, Gissi A, Palestra M, Tinelli C, et al. A population-based survey on gastrointestinal tract symptoms and Helicobacter pylori infection in children and adolescent. Helicobacter. 2002; 7(6): 356-63.

15. Perquin CW, Hunfeld J, Hazebroek-Kampschreur A, van Suijlekom-Smit LW, Passchier J, Koes BW, et al. The natural course of chronic benign pain in childhood and adolescent: a two-year population-based follow-up study. Eur J Pain. 2003; 7(6): 551-9.

16. El-Meki A, Kumar A, Alknawy B, O Al-Ammari, R Moosa, S Quli et al. Comparasion of enzyme immunoassays detecting Helicobacter pylori specific IgG in serum and saliva with endoscopic and biopsy findings in patients with dyspepsia. Indian J Med Microbiol. 2011; 29(2): 136-40.

17. Czinn SJ. Helicobacter pylori infection; detecton, investigation and management. J Pedatr. 2005; 146 (Suppl 3): 21-6.

18. Mansour MM, Al Hadidi Khm, Omar MA. Helicobacter pylori and recurent abdominal pain in children: is there any relation? Trop Gastroenetrol. 2012; 33(1): 55-61.

19. Gold BD, Colletti RB, Abbott M, Czinn SJ, Elitsur Y, Hassall Eet al. Helicobacter pylori in children. Recomandation for diagnosis and tretman. J Pediat Gastroenetrol Nutr. 2000; 31(5): 490-7.

\section{Correspondence to/Autor za korespondenciju}

Osmančević Lejla

University Clinical Center Tuzla

Clinic for Children's Disease

Trnovac bb, 75000 Tuzla

Bosnia and Herzegovina

Tel. 035/303-715, mob 061/ 644-699

e-mail: lejlaosmancevic1967@yahoo.com
20. Gilger M. Gastroenetrologic endoscopy in childre: past, present and future, Current option in Pediatric. 2001; 13(5): 429-34.

21. Walker LS, Lipani T, Green JW, Caines K, Stutts J, Polk DB, et al. Recurrent abdominal pain: Symptom subtypes based on the Rome II criteria for pediatric functional gastrointestinal disorders. J Pediatr Gastroenterol Nutr. 2004; 38(2): 187-91.

22. Thakkar K, Gilger MA, Shulman RJ, El Serga HB. EGD in children with abdominal pain: a systematic review. 2007. In: Database of Abstracts of Reviews of Effects (DARE): Quality-assessed Reviews ŠInternetĆ. York (UK): Centre for Reviews and Dissemination (UK); 1995-. Available from: https://www.ncbi.nlm.nih.gov/books/NBK74647/.

23. Agin M, Kayar Y. The effect of primary duodenogastric bile reflux on the presence and density of helicobacter pylori and on gastritis in childhood. Medicina (Kaunas). 2019; 55(12): 775 .

24. American Academy of Pediatric, North American Society For Pediatric Gastroenetrology, Hepatology and Nutrition. Chronic abdominal pain in children. Pediatrics. 2005; 115(3): 812-5.

25. Frank F, Stricker T, Stallmach T, Braegger CP. Helicobacter pylori in Recurent abdominal pain. J Pediatr Gastroenterol Nutr. 2000; 31(4): 424-7.

26. Kumar M, Yachha SK, Khanduri A, Prasad KN, Ayagari A, Pandey R. Endoscopic, Histologic and microbiologic evaluation of upper abdominal pain with special reference to Helicobacter pylori infection. Indian pediatrics. 1996; 33: 905-9.

27. Mansour MM, Al Hadidi Khm, Omar MA. Helicobacter pylori and recurent abdominal pain in children: is there any relation? Trop Gastroenetrol. 2012; 33(1): 55-61.

28. Dhroove G, Chogle A, Saps A. A million-dollar work-up for abdominal pain: is it worth it. J Pediatr Gastroenetrol Nutr. 2010; 51(5): 579-83.

29. Buchan IE. Arcus Quickstat (Biomedical). Cambridge: Addison Wesley Longman, 1997.

30. Stordal, K. Nygaard E. Bentsen B. Organic abnormalities in recurrent abdominal pain in children. ActaPaediatrica. 2001; 90(6): 638-42.

31. Baysoy G, Ertem D, Ademoglu E, Kotiloglu E, Keskin S, Pehlivanoglu E. Gastric histopathology, iron status and iron deficiency anemia in children with Helicobacter pylori infection. J Pediatr Gastroenterol Nutr. 2004; 38 (2): 146-51.

32. Akbulut UE, Emeksiz HC, Kocak FG, Livaoglu A. Diagnostic yield of esophagogastroduodenoscopy in children with chronic abdominal pain. Arch Med Sci. 2018;14(1): 74-80.

33. Adeniyi OF, Odeghe EA, Lawal MA, Olowu AO, Ademuyiwa A. Recurrent abdominal pain and upper gastrointestinal endoscopy findings in children and adolescents presenting at the Lagos University Teaching Hospital. PLoS One. 2019; 23; 14(5): e0216394. https://doi.org/10.1371/journal.pone.0216394. 